\title{
Fc Receptor-Like Protein 4
}

National Cancer Institute

\section{Source}

National Cancer Institute. Fc Receptor-Like Protein 4. NCI Thesaurus. Code C97594.

Fc receptor-like protein 4 ( $515 \mathrm{aa}, \sim 57 \mathrm{kDa}$ ) is encoded by the human FCRL4 gene. This protein may be involved in $\mathrm{B}$ cell-mediated immune responses. 